\title{
Pemberdayaan Perempuan Dalam Meningkatkan Pendapatan Keluarga Di Desa Beran Kecamatan Ngawi Kabupaten Ngawi
}

\author{
Sumiati \\ Faskultas Ilmu Sosial dan Ilmu Politik, Universitas Soerjo Ngawi, Jl. Cepu No.km. 3, Ngawi, 63218 \\ E-mail: sumiaty688@gmail.com
}

\begin{abstract}
The purpose of this study is to describe women's empowerment in increasing family income in Beran Village, Ngawi District, Ngawi Regency. This type of research is descriptive, aiming to describe women's empowerment in increasing family income in Beran Village, Ngawi District, Ngawi Regency. Respondents in this study were pre-prosperous families in Beran Village, Ngawi Subdistrict, Ngawi Regency, amounting to 57 people. Data collection techniques in this study used questionnaires and documentation. While the data analysis technique uses qualitative descriptive analysis. The research findings show that: (1) The level of welfare in the empowerment of women in increasing family income in Beran Village, Ngawi District, Ngawi District is categorized as good; (2) The level of access to women's empowerment in increasing family income in Beran Village, Ngawi District, Ngawi District is categorized as good; (3) The level of connectivity in empowering women in increasing family income in Beran Village, Ngawi District, Ngawi Regency is categorized as good; (4) The level of participation in empowering women in increasing family income in Beran Village, Ngawi District, Ngawi Regency is categorized as good; (5) The level of equality of power in empowering women in increasing family income in Beran Village, Ngawi District, Ngawi Regency can be categorized as good; and (6) Empowering women in increasing family income in Beran Village, Ngawi District, Ngawi Regency can be categorized as good.
\end{abstract}

Keywords—: women's empowerment; family income.

\section{PENDAhULUAN}

Pemberdayaan perempuan relevan dan sangat penting untuk diperjuangkan secara serius melalui upaya-upaya yang komprehensif, sistematis, dan berkesinambungan. Banyak upaya yang dapat dilakukan secara bersama-sama dalam rangka membantu pemberdayaan kaum perempuan. Kaum perempuan seringkali kurang mendapatkan kesempatan yang cukup untuk berkiprah dalam kehidupan sosial bila dibandingkan dengan laki-laki. Hal ini terjadi karena masih lekatnya ketidakadilan gender dalam masyarakat yang berwujud dalam marginalisasi atau proses pemiskinan ekonomi, subordinasi atau anggapan yang bersifat menyepelekan (tidak penting) kepada kaum perempuan, bahkan kekerasan (violence) termasuk dalam hal bekerja atau justru beban kerja yang lebih panjang atau lebih banyak (double burden). Bentuk ketidakadilan gender ini tidak dapat dipisahpisahkan karena saling terkait dan berhubungan, serta saling mempengaruhi.

Kemiskinan yang dihadapi perempuan membuat mereka tidak banyak memiliki alternatif dalam mencari pekerjaan. Kemiskinan menyebabkan mereka tidak dapat memperoleh kesempatan untuk mengenyam pendidikan yang memadai, menyebabkan mereka tidak dapat berbuat banyak dalam memilih pekerjaan dan menuntut haknya sebagai buruh. Keterampilan yang rendah menyebabkan perempuan miskin berada dalam kedudukan yang lemah dalam menghadapi persaingan menghadapi buruh laki-laki. Mereka juga menghadapi dilema antara keinginan mereka untuk bekerja guna memenuhi kehidupan keluarga dan tugas mereka sebagai ibu rumah tangga. danya pemberdayaan perempuan melalui pendekatan yang mengupayakan proses pendidikan dan penyadaran agar perempuan dapat menggunakan dan memiliki akses maupun control terhadap sumberdaya yang ada di lingkungannya. Sehingga dapat meminimalisir atau mengurangi kemiskinan perempuan sebagai upaya kemiskinan perempuan di Desa Beran pada umumnya.

Berdasarkan pengamatan penulis, kaum perempuan di Desa Beran pada umumnya sudah terberdayakan, baik karena kesadaran diri pada kaum perempuan maupun karena adanya program pemberdayaan oleh pemerintah. Hampir sebagai besar kaum perempuan di Desa Beran memiliki usaha mikro diantaranya usaha tempe, krupuk, jahit, salon dan lain-lain. Keberadaan usaha mikro yang digeluti kaum perempuan tersebut telah mampu meningkatkan ekonomi keluarga.

Pemberdayaan perempuan miskin dapat berhasil apabila menggunakan pendekatan yang mengupayakan proses pendidikan dan penyadaran agar perempuan dapat menggunakan dan memiliki akses maupun kontrol terhadap sumberdaya perdesaan. Diskriminasi terhadap perempuan, subordinasi, dan ketidakdilan dalam pemanfaatan sumberdaya perdesaan menjadi akar masalah kemiskinan di perdesaan. Peningkatan kapasitas perempuan perlu diperhatikan dalam upaya pengentasan kemiskinan di perdesaan. Dalam penelitian ini perhatian utama mengenai perempuan miskin ditujukan agar perempuan miskin dapat menjadi subjek dalam setiap kegiatan mulai dari perencanaan sampai pelaksanaan kebijakan peningkatan kesejahteraan. Peningkatan peran perempuan dalam pengentasan kemiskinan berbasis pemanfaatan sumber daya manusia dapat dilakukan melalui kegiatan ekonomi, sosial, dan perbaikan lingkungan. Masalah dalam penelitian ini dapat dirumuskan sebagai berikut: 
Website : http://sosial.unmermadiun.ac.id/index.php/sosial

Bagaimanakah pemberdayaan perempuan dalam meningkatkan pendapatan keluarga di Desa Beran Kecamatan Ngawi Kabupaten Ngawi?

Berdasarkan rumusan masalah di atas, tujuan penelitian ini adalah sebagai berikut:

1. Untuk mendeskripsikan pemberdayaan perempuan di Desa Beran Kecamatan Ngawi Kabupaten Ngawi.

2. Untuk mendeskripsikan pendapatan keluarga di Desa Beran Kecamatan Ngawi Kabupaten Ngawi.

3. Untuk mendeskripsikan pemberdayaan perempuan dalam meningkatkan pendapatan keluarga di Desa Beran Kecamatan Ngawi Kabupaten Ngawi.

\section{METODE PENELITIAN}

Jenis penelitian yang penulis pergunakan adalah jenis penelitian deskriptif, sedangkan penelitian deskriptif menurut Koentjoroningrat (2000) adalah sebagai berikut: "Suatu metode dalam penelitian suatu kelompok manusia, suatu obyek, suatu kondisi , suatu system pemikiran atau suatu kelas peristiwa pada masa sekarang dan tujuannya adalah membuat deskripsi atau gambaran atau lukisan secara sistematis, actual, akurat mengenai fakta-fakta, serta hubungan antar fenomena yang diselidiki”.

Berdasarkan pendapat tersebut maka penelitian yang penulis lakukan adalah jenis penelitian deskriptif, yang mempunyai tujuan untuk mendiskripsikan secara terperinci mengenai peristiwa atau fenomena sosial dari masing-masing variabel tersebut dan selanjutnya juga mempelajari gambaran antar fenomena tersebut.

Terkait dengan penelitian ini, maka tujuan penelitian ini adalah untuk mendeskripsikan pemberdayaan perempuan dalam meningkatkan pendapatan keluarga di Desa Beran Kecamatan Ngawi Kabupaten Ngawi.

\section{A. Populasi dan Sampel Penelitian}

Berkaitan dengan masalah yang diteliti, terlebih dahulu perlu dipahami tentang apa yang dimaksud dengan populasi. Menurut Hadi (2000), populasi adalah "Individu-individu secara keseluruhan yang akan menjadi sasaran suatu penelitian yang tidak saja manusia tetapi dapat berupa alat, keadaan atau tempat dan atau sebagainya”. Berdasarkan pendapat Sutrisno Hadi (2000), maka populasi dalam penelitian ini adalah keluarga pra sejahtera di Desa Beran Kecamatan Ngawi Kabupaten Ngawi yang berjumlah 57 orang.

Mengingat jumlah populasi tidak terlalu besar, maka tidak perlu diambil sampel penelitian. Hal ini sesuai dengan pendapat Arikunto (2002) yang menyatakan sebagai berikut: “Apabila subyeknya lebih dari 100 (seratus) orang maka sebaiknya diambil antara $10 \%-15 \%$ atau $20 \%-25 \%$ atau lebih, sedangkan jika subyeknya kurang dari 100 orang, maka sebaiknya diambil seluruhnya".

Berdasarkan pendapat Arikunto (2002), di atas, dapat dijelaskan bahwa mengingat jumlah populasi dalam penelitian ini sejumlah 57 orang berarti kurang dari 100, maka tidak perlu diambil sampel. Dengan demikian responden dalam penelitian ini berjumlah 57 orang.

\section{B. Variabel Penelitian}

Menurut Arikunto (2002), yang dimaksud dengan variabel adalah "Gejala yang bervariasi yang menjadi obyek penelitian". Variabel merupakan pengertian yang umum, untuk itu diperlukan indikator. Menurut Arikunto (2002), indikator adalah "memecah variable menjadi kategori-kategori data yang harus dikumpulkan oleh seorang peneliti". Variabel dalam penelitian ini adalah variabel tunggal yaitu Pemberdayaan Perempuan Dalam Meningkatkan Pendapatan Keluarga. Indikator pemberdayaan perempuan meliputi:

1. Welfare (Kesejahteraan)

2. Access (Akses)

3. Consientisation (Konektifitas)

4. Participation (Partisipasi)

5. Equality of Control (Kesetaraan dalam kekuasaan)

Sumber data primer dalam penelitian ini diperoleh melalui jawaban dari angket (kuesioner) yang dibagikan kepada responden, sedangkan sumber data sekunder diperoleh dari data dokumentasi yang ada di tempat penelitian.

\section{Teknik Pengumpulan Data}

Teknik merupakan cara tertentu yang khusus untuk mencari tujuan tertentu. Suatu teknik terdiri dari kegiatan-kegiatan yang teratur dan beraturan, berdasarkan ketentuan-ketentuan sehingga merupakan cara untuk mencapai tujuan. Agar diperoleh data yang benar-benar dapat mendukung dalam pemecahan masalah maka teknik pengumpulan data yang digunakan adalah kuesioner dan dokumentasi.

\section{Analisa Data}

Menurut Nazir (1999), analisis data adalah "Pengelompokan data dengan urutan manipulasi data agar dengan mudah untuk dibaca." Berdasarkan tujuan dan jenis penelitian yang dikemukakan, maka analisis data yang digunakan dalam penelitian ini adalah analisa deskriptif kualitatif. 


\section{III.PEMBAHASAN HASIL PENELITIAN}

Data penelitian tentang pemberdayaan perempuan dalam meningkatkan pendapatan keluarga dibagi menjadi 5 indikator yaitu welfare (kesejahteraan), access (akses), consientisation (konektifitas), participation (partisipasi) dan equality of control (kesetaraan dalam kekuasaan). Berikut ini disajikan interpretasi data per indikator variabel penelitian tentang pemberdayaan perempuan dalam meningkatkan pendapatan keluarga berdasarkan indikadi Desa Beran Kecamatan Ngawi Kabupaten Ngawi.

1. Indikator: Welfare (kesejahteraan)

Berdasarkan rekapitulasi data indikator welfare (kesejahteraan) pada variabel pemberdayaan perempuan dalam meningkatkan pendapatan keluarga di Desa Beran Kecamatan Ngawi Kabupaten Ngawi, dapat diketahui klasifikasi indikator welfare (kesejahteraan) sebagaimana tampak pada tabel 1 berikut ini.

Tabel 1. Klasifikasi Indikator welfare (kesejahteraan) pada Pemberdayaan Perempuan di Desa Beran Kabupaten Ngawi

\begin{tabular}{lccc}
\hline & Kategori & Jumlah Responden & \% \\
\hline Baik & 50 & 87.7 \\
\hline Cukup & 6 & 10.5 \\
\hline Kurang & 1 & 1.8 \\
\hline & Jumlah & 57 & 100.0 \\
\hline
\end{tabular}

Dari tabel tersebut di atas dapat diketahui bahwa dari 57 responden terdapat 50 responden atau 87,7\% termasuk dalam kategori baik, 6 responden atau 10,5 dalam kategori cukup dan terdapat 1 responden atau 1,8\% dalam kategori kurang. Dengan demikian keadaan di lapangan menunjukkan bahwa pemberdayaan perempuan dalam meningkatkan pendapatan keluarga di Desa Beran Kecamatan Ngawi Kabupaten Ngawi berdasarkan tingkat welfare (kesejahteraan) adalah baik.

2. Indikator: Akses

Berdasarkan rekapitulasi data indikator akses pada variabel pemberdayaan perempuan dalam meningkatkan pendapatan keluarga di Desa Beran Kecamatan Ngawi Kabupaten Ngawi, dapat diketahui klasifikasi indikator akses sebagaimana tampak pada tabel 2 berikut ini.

Tabel 2. Klasifikasi Indikator tentang Akses pada Pemberdayaan Perempuan di Desa Beran Kabupaten Ngawi

\begin{tabular}{|c|c|c|}
\hline Kategori & Jumlah Responden & $\%$ \\
\hline Baik & 37 & 64.9 \\
\hline Cukup & 19 & 33.3 \\
\hline Kurang & 1 & 1.8 \\
\hline Jumlah & 57 & 100.0 \\
\hline
\end{tabular}

Dari tabel tersebut di atas dapat diketahui bahwa dari 57 responden terdapat 37 responden atau 64,9\% termasuk dalam kategori baik, 19 responden atau 33,3\% dalam kategori cukup dan terdapat 1 responden atau 1,8\% dalam kategori kurang. Dengan demikian keadaan di lapangan menunjukkan bahwa pemberdayaan perempuan dalam meningkatkan pendapatan keluarga di Desa Beran Kecamatan Ngawi Kabupaten Ngawi berdasarkan tingkat akses adalah baik.

3. Indikator : Konektifitas (Consientisation)

Berdasarkan rekapitulasi data indikator konektifitas (consientisation) pada variabel pemberdayaan perempuan dalam meningkatkan pendapatan keluarga di Desa Beran Kecamatan Ngawi Kabupaten Ngawi, dapat diketahui klasifikasi indikator konektifitas (consientisation) sebagaimana tampak pada tabel 3 berikut ini.

Tabel 3. Klasifikasi Indikator tentang Konektifitas (Consientisation) Pemberdayaan Perempuan di Desa Beran Kabupaten Ngawi

\begin{tabular}{lccc}
\hline & Kategori & Jumlah Responden & Prosentase \\
\hline Baik & 39 & 68.4 \\
\hline Cukup & 17 & 29.8 \\
\hline Kurang & 1 & 1.8 \\
\hline & Jumlah & 57 & 100.0 \\
\hline
\end{tabular}

Dari tabel tersebut di atas dapat diketahui bahwa dari 57 responden terdapat 42 responden atau 73,7\% termasuk dalam kategori baik, 10 responden atau 17,5\% dalam kategori cukup dan terdapat 5 responden atau 8,8\% dalam kategori kurang. Dengan demikian keadaan di lapangan menunjukkan bahwa pemberdayaan perempuan dalam meningkatkan pendapatan keluarga di Desa Beran Kecamatan Ngawi Kabupaten Ngawi berdasarkan tingkat konektifitas (consientisation) adalah baik.

4. Indikator : Partisipasi (Participation)

Berdasarkan rekapitulasi data indikator partisipasi (participation) pada variabel pemberdayaan perempuan dalam meningkatkan pendapatan keluarga di Desa Beran Kecamatan Ngawi Kabupaten Ngawi, dapat diketahui klasifikasi indikator partisipasi (participation) sebagaimana tampak pada tabel 4 berikut ini. 
Website : http://sosial.unmermadiun.ac.id/index.php/sosial

Tabel 4. Klasifikasi Indikator tentang partisipasi pada Pemberdayaan Perempuan di Desa Beran Kabupaten Ngawi

\begin{tabular}{lcc}
\hline \multicolumn{1}{c}{ Kategori } & Jumlah Responden & Prosentase \\
\hline Baik & 44 & 77.2 \\
\hline Cukup & 8 & 14.0 \\
\hline Kurang & 5 & 8.8 \\
\hline Jumlah & 57 & 100.0 \\
\hline
\end{tabular}

Dari tabel tersebut di atas dapat diketahui bahwa dari 57 responden terdapat 44 responden atau 77,2\% termasuk dalam kategori baik, 8 responden atau 14\% dalam kategori cukup dan terdapat 5 responden atau 8,8\% dalam kategori kurang. Dengan demikian keadaan di lapangan menunjukkan bahwa pemberdayaan perempuan dalam meningkatkan pendapatan keluarga di Desa Beran Kecamatan Ngawi Kabupaten Ngawi berdasarkan tingkat partisipasi adalah baik.

5. Indikator : Kesetaraan dalam kekuasaan (Equality of Control)

Berdasarkan rekapitulasi data indikator kesetaraan dalam kekuasaan (equality of control) pada variabel pemberdayaan perempuan dalam meningkatkan pendapatan keluarga di Desa Beran Kecamatan Ngawi Kabupaten Ngawi, dapat diketahui klasifikasi indikator partisipasi (participation) sebagaimana tampak pada tabel 5 berikut ini.

Tabel 5. Klasifikasi Indikator tentang Kesetaraan dalam Kekuasaan pada Pemberdayaan Perempuan di Desa Beran Kabupaten Ngawi

\begin{tabular}{ccc}
\hline Kategori & Jumlah Responden & Prosentase \\
\hline Baik & 38 & 66.7 \\
\hline Cukup & 15 & 26.3 \\
\hline Kurang & 4 & 7.0 \\
\hline Jumlah & 57 & 100.0 \\
\hline
\end{tabular}

Dari tabel tersebut di atas dapat diketahui bahwa dari 57 responden terdapat 42 responden atau 73,7\% termasuk dalam kategori baik, 10 responden atau 17,5\% dalam kategori cukup dan terdapat 5 responden atau 8,8\% dalam kategori kurang. Dengan demikian keadaan di lapangan menunjukkan bahwa pemberdayaan perempuan dalam meningkatkan pendapatan keluarga di Desa Beran Kecamatan Ngawi Kabupaten Ngawi berdasarkan kesetaraan dalam kekuasaan adalah baik.

6. Variabel : Pemberdayaan perempuan dalam meningkatkan pendapatan keluarga

Berdasarkan rekapitulasi data variabel pemberdayaan perempuan dalam meningkatkan pendapatan keluarga di Desa Beran Kecamatan Ngawi Kabupaten Ngawi, dapat diketahui klasifikasi variabel pemberdayaan perempuan dalam meningkatkan pendapatan keluarga sebagaimana tampak pada tabel 6 berikut ini.

Tabel 6. Klasifikasi Variabel Tentang Pemberdayaan Perempuan Dalam Meningkatkan Pendapatan Keluarga di Desa Beran Kabupaten Ngawi

\begin{tabular}{lcc}
\hline Kategori & Jumlah Responden & Prosentase \\
\hline Baik & 42 & 73.7 \\
\hline Cukup & 10 & 17.5 \\
\hline Kurang & 5 & 8.8 \\
\hline Jumlah & 57 & 100.0 \\
\hline
\end{tabular}

Dari tabel tersebut di atas dapat diketahui bahwa dari 57 responden terdapat 42 responden atau 73,7\% termasuk dalam kategori baik, 10 responden atau 17,5\% dalam kategori cukup dan terdapat 5 responden atau 8,8\% dalam kategori kurang. Dengan demikian keadaan di lapangan menunjukkan bahwa pemberdayaan perempuan dalam meningkatkan pendapatan keluarga di Desa Beran Kecamatan Ngawi Kabupaten Ngawi adalah baik.

\section{IV.KESIMPULAN DAN SARAN}

\section{A. Kesimpulan}

Berdasarkan pada pembahasan yang telah diuraikan pada bab-bab sebelumnya maka dapat diambil suatu kesimpulan sebagai berikut:

1. Tingkat welfare (kesejahteraan) dalam pemberdayaan perempuan dalam meningkatkan pendapatan keluarga di Desa Beran Kecamatan Ngawi Kabupaten Ngawi dikategorikan baik.

2. Tingkat akses dalam pemberdayaan perempuan dalam meningkatkan pendapatan keluarga di Desa Beran Kecamatan Ngawi Kabupaten Ngawi dikategorikan baik.

3. Tingkat konektifitas (consientisation) dalam pemberdayaan perempuan dalam meningkatkan pendapatan keluarga di Desa Beran Kecamatan Ngawi Kabupaten Ngawi dikategorikan baik.

4. Tingkat partisipasi dalam pemberdayaan perempuan dalam meningkatkan pendapatan keluarga di Desa Beran Kecamatan Ngawi Kabupaten Ngawi dikategorikan baik.

5. Tingkat kesetaraan kekuasaan dalam pemberdayaan perempuan dalam meningkatkan pendapatan keluarga di Desa Beran Kecamatan Ngawi Kabupaten Ngawi dapat dikategorikan baik.

6. Pemberdayaan perempuan dalam meningkatkan pendapatan keluarga di Desa Beran Kecamatan Ngawi Kabupaten Ngawi dapat dikategorikan baik. 
Website : http://sosial.unmermadiun.ac.id/index.php/sosial

\section{B. Saran}

Berdasarkan kesimpulan hasil penelitian, dapat disampaikan saran sebagai berikut:

1. Hendaknya pemerintah secara berkala dan terprogram memberikan pemahaman terhadap regulasi dan peraturan pemerintah terkait dengan legalitas dunia usaha khususnya yang terkait dengan pemberdayaan perempuan.

2. Hendaknya pemerintah pusat maupun pemerintah daerah bersama-sama dapatnya membantu kaum perempuan dalam membuat akses usaha baru. Hal ini dimaksudkan agar dengan adanya usaha baru tersebut dapat menambah penghasilan keluarga dan pada akhirnya dapat meningkatkan kesejahteraan kerluarga.

Hendaknya pemerintah memberikan pelatihan teknologi dan informasi yang keberadaan saat ini dirasakan mampu meningkatkan pendapatan atau omzet dunia usaha, misalnya bagaimana kiat dan langkah-langkah pemasaran secara on-line dan lain sebagainya.

\section{DAFTAR PUSTAKA}

Abdul Syani, 2002. Sosiologi Skematika Teori dan Terapan, Jakarta: PT. Bumi Aksara, Cetakan ke-2.

Boediono. 2002. Pengantar Ekonomi, Jakarta: Erlangga.

Departemen Pendidikan dan Kebudayaan, 1998. Kamus Besar Bahasa Indonesia, Jakarta: Balai Pustaka.

Edi Suharto. 2009. Membangun Masyarakat Memberdayakan Rakyat, Cetakan ke-3, Bandung: PT. Refika Aditama.

Edi Suharto. 2003. Pembangunan Kebijakan dan Kesejahteraan Sosial. Bandung: Mizan.

Hadari Nawawi. 1999. Metode Penelitian Bidang Sosial, Yogyakarta: UGM.

Ismah Salman. 2005. Keluarga Sakinah dalam Aisyiyah. Jakarta: PSAP Muhammadiyah. Cetakan ke-1.

K.Suhendra. 2006. Peranan Birokrasi Dalam Pemberdayaan Masyarakat, Cetakan ke-1, Bandung: Alfabeta.

Kartini Kartono. 1999. Psikologi Wanita, Mengenal Gadis Remaja dan Wanita Dewasa, Bandung: Mandar Maju. Cetakan ke-2.

Kartodirdjo dkk., 2013. Pendekatan Ilmu Sosial Dalam Metodologi Sejarah. Jakarta: PT. Gramedia Pustaka Utama.

Koentjoroningrat. 2000. Metode Penelitian. Cetakan 2. Jakarta: Ghalia Indonesia.

Mansour Fakih. 1999. Analisis Gender dan Transformasi Sosial, Yogyakarta: Pustaka Pelajar, Cetakan ke-1.

Murtadlo Muthahari. 1995. Hak-hak Wanita dalam Islam, Jakarta:Lentera. Cetakan ke-3.

Muhibbin Syah. 2008. Psikologi Pendidikan, Bandung: PT Remaja Rosdakarya.

N. Marbun. 2003. Kamus Manajemen, Jakarta: Pustaka Sinar Harapan.

Nugraheny Mustika, 2009. Buku Ajar Ilmu Gizi Keluarga. Yogyakarta: Tosca Enterprice

Prijono, S. Onny dan Pranarka, A.M.W. 1996. Pemberdayaan : Konsep, Kebijakan dan Implementasi, Jakarta: CSIS.

Reksoprayitno. 2004. Sistem Ekonomi dan Demokrasi Ekonomi, Jakarta: Bina Grafika.

Riant Nugroho. 2008. Analisis Kebijakan Publik. Bandung: CV. Alfabeta.

Roosganda Elizabeth. 2007. Pemberdayaan Wanita Mendukung Stategi Gender Mainstreaming dalam Kebijakan Pembangunan Pertanian di Pedesaan. Jurnal Forum Penelitian Agro Ekonomi. Volume 25. No. 2. 2007

Soekartawi. 2002. Faktor-faktor Produksi, Jakarta: Salemba Empat

Sudarman Toweulu. 2001. Ekonomi Indonesia. Jakarta: Raja Grafindo.

Suharsimi Arikunto, 2002, Prosedur Penelitian Suatu pendekatan Praktek, Edisi Revisi, Jakarta: Reneka Cipta.

Sutrisno Hadi, 2000. Statistika Jilid I, Yogyakarta: Fakultas Psikologi UGM.

T. Gilarso. 2002. Pengantar Ilmu Ekonomi Makro. Yogyakarta: IKAPI. Yogyakarta. Edisi Pertama.

Undang-Undang Nomor 6 Tahun 2014 tentang Desa.

Winarno Surachmad, 1999. Pengantar Penelitian Ilmiah, Dasar dan Metode Teknik, Bandung: Tarsito.

Zaitunah, Subhan. 2004. Kekerasan Terhadap Perempuan. Yogyakarta: Pustaka Pesantren.

Zakiyah. 2010. Pemberdayaan Perempuan oleh Lajnah Wanita, Jurnal Pengkajian Masalah Sosial Keagamaan, XVII, 01, Januari-Juni 2010. 